\title{
Exciting innovations for assessment in Aotearoa
} New Zealand

\section{JENNY POSKITT}

An assessment seminar series in the April 2018 school holidays saw the launch of the New Zealand Assessment Institute (NZAI), and growing excitement about innovative assessment practice across the primary and secondary school sectors. What happened at this seminar series to generate enthusiasm, especially given schools' uncertainty about assessment in the midst of considerable change in education this year? What is NZAI? This Assessment News article informs readers about the Rethinking Assessment in Aotearoa/New Zealand seminars, and describes the "who, what, and why" of NZAI.

\section{Rethinking assessment in Aotearoa New Zealand}

Since the government announced the cessation of National Standards reporting, and the review of NCEA, teachers have sought information and guidance about assessment requirements. This thirst for information led 400 teachers/educators to attend the Rethinking Assessment in Aotearoa/ New Zealand full-day seminars in Christchurch, Wellington, and Auckland during the April school holidays.

The format was similar in each venue with a mix of keynote addresses, school workshop presentations, discussions, and networking opportunities. Two keynote presenters spoke at the three seminars (Mary Chamberlain-formerly of the Ministry of Education, now of Evaluation
Associates; and Esther Smaill_-recent PhD graduate from University of Otago), while Dr Karen Poutasi (Chief Executive, NZQA) spoke in Wellington, and Professor Welby Ings (AUT) in Auckland. These keynote speakers informed and challenged delegates' thinking across a range of assessment topics, such as:

- Where have we been and where are we going in New Zealand assessment?

- The power of social moderation to stimulate professional learning in assessment, curriculum and pedagogy (ideal for Kāhui Ako).

- The need for learning and assessment/qualification approaches to be responsive to 2Ist-century needs.

- The challenge to make learning visible through a wider range of evidence.

The keynotes made it clear that New Zealand has a strong history in assessment for learning (e.g., statements in Tomorrow's Standards (Ministry of 
Education, 1990); The New Zealand Curriculum (Ministry of Education, 2007); and Directions for Assessment in New Zealand (Absolum, Flockton, Hattie, Hipkins, \& Reid, 2010)), and has invested in teachers' professional learning in assessment for several decades. Contemporary ways of assessing skills required for 21st-century learning were further stimulation for thinking how might assessments help learners develop agency and capabilities to create new solutions to social, environmental, financial, and political threats to peace and wellbeing? How do/could we define, and show, progress in a range of capabilities?

Teachers' reported that their thinking was challenged in these keynote addresses. They too saw a need for greater clarity and shared understandings about assessment, manageability of assessment (including the need to review, streamline, and improve assessment processes in the classroom and school), and to develop more purposeful assessment by using it to inform and adjust learning and teaching.

Workshop presentations traversed a range of topics based on practical assessment experiences in schools. Delegates considered whether, or how, they might adapt ideas for their context. Popular in Wellington was the Education Review Office workshop that clarified expectations for school reviews. Teachers appreciated the main message that, since "less [assessment] is more [learning time]", it is important to focus on the quality rather than quantity of assessment, and only assess what will be used to inform learning and teaching.

Across the 3 seminar days, secondary school teachers discussed topics such as project-based and cross-curricular tasks for NCEA credits, flipped classrooms, integrated learning and assessment, and development of graduate profiles. Delegates with Kāhui Ako interests considered co-construction of success criteria and reporting with students/whānau, shared understandings about curriculum levels and moderation, and how to use assessment to improve learning and teaching. Primary school teachers' workshop topics looked at, for example: the value of the progress and consistency tool $(\mathrm{PaCT})$; how to utilise the strengths of National Standards and abandon the limitations; using learning progressions and key competencies to promote assessment for learning; and optimising digital tools and platforms for learning, assessment, and reporting purposes.

How did delegates respond to these seminar days? Verbal and written feedback indicated that the teachers and educators who attended were reassured, and inspired, by their colleagues' innovative expertise in the workshops. Delegates appreciated opportunities both to learn about national and international trends and research in assessment, and to learn what other schools were doing.
They also valued networking and collaborating. Many expressed appreciation for the opportunities created by NZAI.

A fortnight later, when PLD providers within NZAI visited a number of the schools involved, they found an increased confidence in their assessment with a determined focus on purposeful assessment. All desired to be further involved in NZAI.

\section{What is NZAI?}

The New Zealand Assessment Institute (NZAI) is a newly formed learning network, composed of principals, teachers, professional-development facilitators, researchers, and government agency personnel with interests and expertise in assessment. NZAI was cofounded by Dr Jenny Poskitt (Massey University) and Michael Absolum (Director, Evaluation Associates). Supported by an interim executive committee (of principals, professional-development facilitators, researchers, and government agency personnel), they established an organisational structure, a website (www. nzai.org.nz) and seminar series to ascertain levels of interest in assessment, and information that the sector and stakeholders seek.

\section{Why was NZAI established?}

NZAI was formed on the belief that greater awareness and understanding of the various roles played by policy personnel (e.g., Ministry of Education), policy influencers (e.g., researchers, PLD facilitators, teacher unions, NZCER), and policy actors (teachers and schools), could lead to effective partnerships and more aligned policy, research, and practice in assessment. Its purpose is threefold: to develop and strengthen relationships across the education sector and stakeholder groups; to increase assessment capability; and improve learning and teaching for the betterment of all learners.

\section{What will NZAI do, and offer to members?}

NZAI is an independent body that seeks to develop relationships/networks across the sector and stakeholders in education, by creating face-to-face and virtual opportunities for members to meet and engage in conversations about assessment. To enhance access to "best" practice and information in assessment, NZAI intends to be a purveyor of both practical and theoretical assessment information and resources, and improve access to pertinent assessment research reports and publications. It encourages members to share information about the latest 
developments in assessment. Finally, NZAI will have an advocacy role in providing evidence-based advice and input into assessment matters, nationally and internationally. Its strength and relevance is however, dependent on active engagement by cross-sector/stakeholder members with willingness to share ideas, resources, interest, and expertise in educational assessment, especially in contexts with indigenous peoples.

Exciting developments in assessment are occurring. To share, or learn about, assessment-related information on the latest networks, events, resources and what is happening around Aotearoa/New Zealand, or to join NZAI please refer to www.nzai.org.nz.

\section{References}

Absolum, M., Flockton, L., Hattie, J., Hipkins, R., Reid, I. (2009). Directions for assessment in New Zealand: Developing students' assessment capabilities. Retrieved from http:// assessment.tki.org.nz/content/download/5374/46264/ version/4/file/Directions+for+Assessment+in+New+Zealand. PDF

Ministry of Education. (1990). Tomorrow's standards: The report of the ministerial working party on assessment for better learning. Wellington: Learning Media.

Ministry of Education. (2007). The New Zealand curriculum. Wellington: Learning Media. Retrieved from nzcurriculum.tki.org.nz/The-New-Zealand-Curriculum
Dr Jenny Poskitt is Associate Head of the Institute of Education, Massey University, and President of the New Zealand Assessment Institute. Jenny began her career as a primary school teacher and since that time developed teaching and research interests in assessment, professional learning, adolescent learning and engagement. She serves on various national advisory groups (e.g., IES, RNZGP Education Advisory Group) and working parties for the Education Council and NZCER. She is also an invited member of the International Educational Assessment Network (IEAN). Email: j.m.poskitt@massey.ac.nz 